\title{
Environmental assessment of Iraq's water system
}

\author{
(C) Falih Hasan Abdulhussein Al-Fradi, Yulia A. Smyatskaya, ${ }^{*+}$ and Natalia A. Politaeva \\ Civil Engineering Institute. Peter the Great St. Petersburg Polytechnic University. \\ Polytechnicheskaya St., 29. St. Petersburg, 194064. Russia. \\ Phone: +7921868 6554.E-mail: Makarovayulia169@mail.ru
}

\begin{abstract}
*Supervising author; ${ }^{+}$Corresponding author
Keywords: Iraq's water supply, river quality, oil products, heavy metals.
\end{abstract}

\begin{abstract}
The main sources of water supply for the Iraq industries and settlements are water resources of Tigris and Euphrates rivers. The settlements, agriculture and industry facilities, primary located along the banks of the main rivers and their tributaries, together negatively influence the surface waters of the region. The search for sources for water supply is a serious problem due to the high pollution of water in settlements, the growing problem of desertification in the region, the reduction of water volumes in the Tigris and Euphrates rivers due to the construction of dams. A major threat to surface water quality is emergency and unauthorized industrial and domestic discharges, which can be extremely dangerous for water sources. Traditional water treatment technologies are ineffective and do not provide reliable drinking water quality for the population. The water system of the Tigris rivers in Baghdad is characterized by a high content of dissolved substances, sulfates, calcium, some metals $(\mathrm{Pb}, \mathrm{Cd}, \mathrm{Hg})$, bacteriological indicators. Significant pollution is observed in the Euphrates River, for such parameters as turbidity, suspended and dissolved substances, BOD, sodium, calcium, sodium chloride. Heavy metal pollution is noted in some sections of the river near Hill. The objective of this study was to examine and analyze the geoecological condition of water resources of Iraq as the essential source of water supply for the country. The information was gathered from literature, Internet and own research. The study showed that the water resources of all river systems in Iraq were polluted by some physicochemical parameters which do not satisfy to the Iraq standards.
\end{abstract}

\section{References}

[1] M.G. Yasoveev, A.-D.Kh.D Ayad, G.K. Khudaykulyeva. Geoecological problems of the Middle East and Central Asia. Veci BDPU. 2013. Ser.3. No.3. P.40-44. (russian)

[2] Desk study on the environment in Iraq. United Nations Environment Programme. Nairobi, Kenya. 2003. 98p.

[3] Global Environment Outlook (Geo 2000): UNEP Millennium Environment Report. UNEP. Tver. 2000. 398p. (russian)

[4] V. Kruglov. Iraq: New wars against ecology. Russia and the Muslim world. 2003. No.12. P.86-89. (russian)

[5] S.S. Zhiltsov, I.S. Zonn. The fight for water. Security Index. 2008. Vol.14. No.3(86). P.49-60. (russian)

[6] M.N. Shamout, G. Lahn. The Euphrates in crisis. Channels of cooperation for a threatened. Energy, Environment and Resources. April 2015 [Электронный ресурс]. Систем. требования: Internet browser. URL: https://www.chathamhouse.org/publication/euphrates-crisis-channels-cooperation-threatened-river (дата обращения: 22.04.2017).

[7] S.M. Al-Rawi. Contribution of man-made activities to the pollution of the Tigris within Mosul Area, IRAQ. International Journal of Environmental Research and Public Health. 2005. Vol.2(2). P.245-250

[8] H.S. Al- Bahrani. Water quality deterioration of the Euphrates River before entering Iraqi lands. WIT Transactions on Ecology and the Environment. 2014. Vol.182. doi:10.2495/WP140011

[9] A.J. Kadhem. Assessment of Water Quality in Tigris River-Iraq by Using GIS Mapping. Natural Resources. 2013. Vol.4. P.441-448.

[10] Al Dahaan, S.A.M. and N. Al-Ansari. Salinity functions for groundwater at Safwan, South Iraq//Journal of Environmental Hydrology. 2019. Vol.27. P.7. [Electronic resource]. System. requirements: Internet browser. URL: http://www.hydroweb.com/journal-hydrology-2019-paper-7.html (date of the application: 11.06.2020). 
[11] A.M. Rabee, Ya.F. Al-Fatlawy, Abd own A.-Al-H.N., M. Nameer. Using pollution load index (PLI) and geoaccumulation index (I-Geo) for the assessment of heavy metals pollution in Tigris River sediment in Baghdad region. Journal of Al-Nahrain University. 2011. Vol.14. No.4. P.108-114.

[12] R.N. Ajmi. Investigating mercury existence in some stations in Tigris River in. Journal of Environmental Science and Engineering. 2013. №A2. P.203-208.

[13] Kh.K. Al-Bayatti, K.H. Al-Arajy, S.H. Al-Nuaemy. Bacteriological and physicochemical studies on Tigris River near the water purification stations within Baghdad Province. Journal of Environmental and Public Health. 2012. Vol.2012. doi:10.1155/2012/695253

[14] E.A. Al-Heety, A.M. Turky, E.M. Al-Othman. Physico-chemical assessment of Euphrates River between Heet and Ramadi Cities, Iraq. Journal of Water Resource and Protection. 2011. No.3. P.812-823.

[15] S.M. Awadh, R.M. Ahmed. Hydrochemistry and pollution probability of selected sites along the Euphrates River, Western Iraq. Arab J Geosci. 2013. No.6. P.2501-2518.

[16] F.M. Alkam, M.j.S. Al-Haidarey, K.K. Alasedi. A study of some physicochemical parameters and heavy metals in the Diwaniyah River. International Journal of Science and Research. 2014. Vol.3. Iss.6. [Электронный ресурс]. Систем требования: Adobe Acrobat Reader. URL: www.ijsr.net.

[17] E.M. Salah, I.K. Al-Hiti, K.A. Alessawi. Assessment of Heavy Metals Pollution in Euphrates River Water, Amiriyah Fallujah, Iraq. Journal of Environment and Earth Science. 2015. No.15. P.59-70.

[18] G.M. Al-Maliki, Kh.Kh. Al-Khafaji, A.J. Al-Shemary. Study of the Bacterial pollution and some Heavy Metals in Freshwater snail (Pomacea canaliculata) in Shatt Al-Arab river. Journal of Basrah Researches (Sciences). 2015. Vol.41. No.3. P.44-50.

[19] Abbas, N., S.A. Wasimi, N. Al-Ansari, and N. Sultana. Water resources problems of Iraq: Climate change adaptation and mitigation. Journal of Environmental Hydrology. 2018. Vol.26. P.6. [Electronic resource]. System. requirements: Internet browser. URL: http://www.hydroweb.com/journal-hydrology2018-paper-6.html (date of the application: 11.06.2020).

[20] K.M. Shareef, S.G. Muhamad. Natural and drinking water quality in Erbil, Kurdistan. Current World Environment. 2008. Vol.3(2). P.227-238.

[21] A.S. Al-Adili, Q.A. Al-Suhail. Spectral analysis of some selected hydrochemical parameters of Diyala river in Iraq. Fourteenth International Water Technology Conference, IWTC14 2010 Cairo, Egypt. Cairo. 2010. P.691-710.

[22] E.J. Abdullah. Evaluation of Surface Water Quality Indices for Heavy Metals of Diyala River-Iraq. Journal of Natural Sciences Research. 2013. Vol.3. No.8. P.63-69.

[23] Al Majmai Salih Saud Yakub. The study of geoecological problems in the area of the Diala River. Successes of Modern Science. 2016. Vol.3. No.5. P.28-30. (russian)

[24] Al Majmai Salih Saud Yakub. Implementation of environmental measures to improve the geoecological state of the Diala River. Successes of Modern Science. 2017. Vol.4. No.2. P.45-48. (russian) 